\title{
Regulasi Hukum dalam Transaksi E-Commerce: Menuju Optimalisasi Pemanfaatan Teknologi Informasi
}

\author{
Budi Agus Riswandi
}

\begin{abstract}
The development of informational technology have appeared new transaction pattern that is called electronic commerce (e-commerce). E-commerce is a transaction pattern which uses technology of information. Through e-commerce transaction, it gained much of things economically. But if it is viewed from jurisdical side, the e-commerce transaction model still have problem in law. Regulation of law support for optimalisation of utility the techonology of information, especially in the e-commerce therefore must be realized.. Concretization of this law regulation is realized in the form of the management on relations involved in transaction and it is not management on its technology.
\end{abstract}

\section{Pendahuluan}

Perkembangan internet di Indonesia memang seperti tidak terduga sebelumnya. Beberapa tahun yang lalu internet dikenal oleh sebagian kecil orang yang mempunyai minat di bidang komputer. Tahun-tahun terakhir ini, pengguna jasa internet meningkat secara sangat pesat, meski ada pendapat yang mengatakan bahwa kebanyakan pengguna internet di Indonesia baru sebatas untuk hiburan dan percobaan. ${ }^{1}$

Kini internet sudah menjadi permasalahan khusus semenjak dimanfaatkan dalam kegiatan perdagangan atau bisnis yang dikenal

dengan transaksi e-commerce. Diakui secara ekonomi, pemanfaatan internet telah memberikan nilai tambah dalam mempercepat proses transaksi, tetapi secara yuridis masalah pemanfaatan internet ini sangat riskan bagi para pihak karena karakteristiknya sangat berbeda dengan transaksi pada umumnya, sehingga sulit dijangkau oleh aturan-aturan hukum yang konvensional.

Alasan ini didasarkan kepada suatu realitas bahwa transaksi e-commerce yang memanfaatkan media internet sifatnya tidak

${ }^{1}$ Asri Sitompul. 2001. Hukum Internet Pengenalan Mengenai Masalah Hukum di Cyberspace. Bandung: Citra Aditya Bakti. Hilm.1. 
hanya sebatas lingkup lokal atau nasional, tetapi aktivitas transaksi e-commerce sudah berjalan tanpa batas (bonderless world). Dalam kajian hukum, hal ini memuncul persoalan; choice of law, choice of forum, dan masalah yurisdiksi. Kendala semacam ini bukan berarti hukum tidak patut untuk mengaturnya. Justru, tantangan tersendiri bagaimana hukum mampu memfasilitasi perkembangan-perkembangan tersebut yang tentunya diorientasikan dalam upaya optimalisasi pemanfaatan teknologi informasi..

\section{Arti dan Karakteristik Transaksi E-Commerce}

Perkembangan sains dan teknologi membawa dampak yang signifikan terhadap sistem perekonomian global dewasa ini. Teknologi telah membawa kontribusi yang begitu dominan terhadap perekonomian suatu negara, baik dalam sistem ekonomi secara makro maupun skala mikro. Era ekonomi berbasis informasi, menjadikan teknologi komputer memiliki peranan yang sangat menentukan, seperti praktik bisnis yang sangat tergantung pada IT (information technology), khususnya komputer.?

Perdagangan dengan mengunakan sarana internet, tentunya akan sangat memberikan kemudahan dan efisiensi yang sangat tinggi baği mereka yang memerlukan produk atau barang yang diinginkan. Mulai dari produk yang bersifat sederhana maupun yang memerlukan sarana delivery antara negara. ${ }^{3}$

Electronic Commerce (disingkat e-commerce) sebagai sarana berbisnis menggunakan jaringan komputer, sebenarnya sudah dikenal sejak dua puluh tahun lalu, yaitu sejak akhir tahun '70-an dan awal tahun '80an. Generasi pertama e-commerce dilakukan hanya antar perusahaan berupa transaksi jual beli yang difasilitasi oleh Electronic Data Interchange (EDI). Dalam transaksi jual beli elektronik banyak aspek-aspek hukum yang bërsentuhan langsung maupun tidak langsung. E-Commerce melalui EDl ini sifatnya eksklusif, yaitu terbatas hanya antar perusahaan (business-to-business). Namun sejak awal tahun '90-an, e-commerce lebih banyak menggunakan fasilitas internet yang sifatnya jauh lebih inklusif dan sangat terbuka. Hal ini terutama dikaitkan dengan peluncuran World Wide Web (Www) pada tahun 1992 yang merupakan salah satu alat (tool) Internet yang populer untuk membuat, memanipulasi dan memanggil dokumen-dokumen yang terdiri dari audio, video, informasi grafis dan teks. ${ }^{4}$

Bahkan secara de facto web ini sudah menjadi standar untuk melakukan navigasi, menerbitkan informasi dan mengeksekusi transaksi pada intemet dan intranet (jaringan komputer intern organisasi/perusahaan). Melalui jaringan internet inilah, e-commerce, dikenal oleh kalangan yang lebih luas meliputi

2Ade Maman Suherman. 2002. Aspek Hukum dalam Ekonomi Global. Jakarta: Ghalia Indonesia. Hlm. 179.

"Indra Safitri. "Hukum tentang Cyber dan Teknologi di Pasar Modal Indonesia." http:// business. fortunecity.com/buffett/842/art000011 hukumcyber.

${ }^{4}$ Redynal Saat. "Electronic Commerce Peluang dan Kendala." http://www.cyberlaw./kht.org/arsip/ ecommerce peluang atau kendala red.htm 
pelaku bisnis berskala besar sampai pelaku bisnis individual. Jangkauan area pasarnya meliputi seluruh dunia atau setidaknya negaranegara di dunia yang telah mempunyai jaringan Internet tersebut. Tidaklah heran sejak saat itu tumbuh subur perusahaanperusahaan maya baik yang sebelumnya telah ada atau sama sekali baru. Sekedar contoh dapat disebutkan di sini yang sama sekali baru memanfaatkan peluang e-commerce ini adalah Amazon.com, sebuah toko maya yang berkonsentrasi pada penjualan buku dan musik yang bermarkas di Amerika Serikat. Sebagai toko maya, Amazon.com mampu menyajikan lebih dari 2,5. juta buku kepada para "pengunjungnya". Bandingkan dengan sebuah toko buku tradisional terbesar di Amerika Serikat yang hanya mampu menyediakan sekitar 150.000 buku. $^{5}$

Menurut World Trade Organization (WTO), cakupan e-commerce meliputi bidang produksi, distribusi, pemasaran, penjualan, dan pengiriman barang atau jasa melalui elektronik, sedangkan OECD (Organization for Economic Cooperation and Development) menjelaskan bahwa e-commerce adalah transaksi berdasarkan proses dan transmisi data secara elektronik. Selain dari dua lembaga internasional tersebut, Alliance for Global Business, suatu asosiasi di bidang perdagangan terkemuka mengartikan e-commerce sebagai seluruh transaksi nilai yang melibatkan transfer informasi, produk, jasa atau pembayaran melalui jaringan elektronik sebagai media. ${ }^{6}$

Ada beberapa faktor yang memperkuat proses transaksi perdagangan yang semula didasarkan kepada kertas, beralih ke media elektronik. Pertama, e-commerce memiliki kemampuan untuk menjangkau lebih banyak pelanggan dan setiap saat pelanggan dapat mengakses seluruh informasi yang up date dan terus menerus; Kedua, e-commerce dapat mendorong kreatifitas pihak penjual secara cepat dan tepat dan pendistribusian informasi yang disampaikan berlangsung secara periodik; Ketiga, e-commerce dapat menciptakan efisiensi yang tinggi , murah serta informatif; Keempat, e-commerce dapat meningkatkan kepuasan pelanggan, dengan pelayanan yang cepat, mudah, aman dan akurat.7

Dalam e-commerce ada bermacammacam jenis transaksi yang terjadi apabila dilihat dari hubungan subyek atau pelakunya, diantaranya: ${ }^{8}$

1. Business to business (B2B), model transaksi e-commerce ini banyak digunakan sekarang. Hal ini meliputi Interorganizational System (IOS) transaksi dengan segera dari transaksi pasar elektronik antar organisasi.

2. Business to consumer (B2C), transaksi retail dengan pembelanjaan (shopper) individu. Bentuk pembelanjaan seperti di

\footnotetext{
s/bid.

${ }^{6}$ Ade Maman Suherman. Op.Cit.HIm. 179.

"Indra Safitri. "Commerce dalam Perspektif Hukum." http://business.fortunecity.com/buffett/842/ art080399 ecommerce.htm

${ }^{8}$ Efraim Turban, et.el. 2001. Electronic Commerce: Manajemen Perspective. New Jersey: Prentice Hall.HIm. 13. Lihat juga Ridwan Khairandy."Pembaharuan Hukum Kontrak dalam Aktivitas E-Commerce." Jurnal Hukum No. 16 Vol. 8 Maret 2001. Hlm. 47HIm. 10-11.
} 
Amazon.com adalah konsumen atau costumer.

3. Consumer to consumer (C2C), dalam katagori ini konsumen menjual dengan langsung kepada konsumen. Contohnya individu menjual yang diklasifikasikan ads (e.q. www.clasified2000.com) pemilikan kediaman (residential property), dan mobil. Pengiklanan jasa personal pada internet dan menjual ilmu pengetahuan dan keahlian merupakan contoh lain dari $\mathrm{C} 2 \mathrm{C}$. Beberapa situs pelelangan (auction) membolehkan individu untuk meletakkan item. Pada akhirnya banyak individu menggunakan internet dan jaringan organisasi internal lainnya ke pelelangan item untuk penjualan atau pelayanan.

4. Consumer to business (C2B), kategori ini meliputi individu yang menjual produk atau jasa untuk organisasi. Selama individu yang menjual mempengaruhi (interact) dengan mereka dan penutupan transaksi.

5. Nonbusiness e-commerce, meningkatkan sejumlah lembaga nonbisnis seperti; lembaga akademik, organisasi non profit, organisasi keagamaan, organisasi sosial, dan agen pemerintahan menggunakan bentuk ecommerce yang akan mereduksi pembiayaan atau memperbaiki oprasional dan pelayanannya.

6. Intrabusiness organizational e-commerce, kategori ini meliputi semua kegiatan organisasi internal, biasanya berupa internet.

Praktiknya, model transaksi yang banyak dipakai oleh user/konsumen sampai saat ini adalah model Business to Business (B2B) dan Business to Consumer (B2C). Kedua model transaksi e-commerce ini mempunyai ciri dan karakteristik masing-masing. Transaksi B2B cirinya para pelaku adalah pengusahapengusaha baik pribadi hukum maupun badan hukum dan para pelaku tersebut bukanlah end-user dari produk atau obyek ecommerce itu sendiri. Dalam B2B ini transaksi yang terjadi bukan hanya jual-beli, namun dapat berupa konsinyasi ataupun hanya pertukaran data atau dokumen-dokumen perdagangan (misainya Electronic Data Interchange/EDI). ${ }^{9} \quad$ Sementara dari segi karakteristik B2B mempunyai karakteristik sebagai berikut: ${ }^{10}$

1. Trading partners yang sudah diketahui dan umumnya memiliki hubungan (relationship) yang cukup lama. Hal ini disebabkan karena sudah mengenal lawan komunikasi, maka jenis informasi yang dikirim dapat disusun sesuai kebutuhan dan kepercayaan (trust).

2. Pertukaran data (data exchange) berlangsung berulang-ulang dan secara berkala, misalnya setiap hari dengan format data yang telah disepakati bersama. Dengan kata lain, servis yang digunakan sudah tentu. Hal ini

9Sheilla Hardhini. "Penyelesaian Sengketa Business to Business Dan Business to Consumer Electronic Commerce Melalui Litigasi dan Arbitrase di Indonesia." http://www.cyberlaw./kht.org/penelitian/ penyelesaian sengeta b2b\&b2c litigasi arbitrasi she.htm

10/bid. 
memudahkan pertukaran data untuk dua badan usaha yang menggunakan standar yang sama.

3. Salah satu pelaku dapat melakukan inisiatif untuk mengirimkan data, tidak harus menunggu mitranya.

4. Model yang umum digunakan adalah peer-to-peer atau dari satu titik ke titik lainnya, misalnya dari komputer yang satu ke komputer lainnya, dimana processing intelligence dapat didistribusikan di kedua pelaku bisnis.

Berbeda dengan B2C yang pada umumnya menggunakan jaringan terbuka seperti internet sehingga informasi dapat disebarkan ke umum melalui web-commerce, maka B2B memiliki ciri-ciri yang berbeda dimana informasi hanya dipertukarkan melalui mitra bisnisnya walaupun hal ini dapat juga dilakukan melalui internet (contohnya EDI over internet). Untuk dapat melakukan ini tentu saja sebelumnya sudah harus terjalin hubungan bisnis antara para pihak yang melakukan transaksi. Ada dua jenis model transaksi B2B yaitu pertukaran data atau dokumen bisnis (the business to business exchange of data) biasanya dengan EDI, dan jual beli (business to business buying and selling).

B2C merupakan model transaksi e-commerce, di mana salah satu pelakunya adalah sebagai end-user. Secara mudah transaksi B2C pada dasarnya sama dengan jual beli, pembeli berkedudukan sebagai end-user atas barang yang diperdagangkan. Ciri-ciri transaksi $\mathrm{B} 2 \mathrm{C}$ adalah: ${ }^{11}$
1. Terbuka untuk umum, dimana informasi disebarkan ke umum.

2. Servis yang diberikan bersifat umum (generic) dengan mekanisme yang dapat digunakan oleh khalayak ramai. Sebagai contoh, karena sistem web sudah umum digunakan maka servis diberikan dengan menggunakan basis web.

3. Servis diberikan dengan berdasarkan permohonan (on demand). Konsumen melakukan inisiatif dan produser harus siap memberikan respon sesuai dengan permohonan.

Dengan melihat ciri dan karakteristik dari model-model transaksi e-commerce, maka apabila para pelaku bisnis mampu mengoptimalkan kemampuan dalam transaksi ini akan meraup keuntungan yang. sangat besar. Namun, yang utama untuk mencapai itu haruslah memperhatikan aspek manajemen dari pelaku bisnis. Dalam kaitan ini Malcolm Frank dalam The Realities of Web-based Electronic Commerce menyarankan tujuh langkah menuju sukses dalam melakukan e-commerce: ${ }^{12}$

1. E-Commerce harus dipandang sebagai sistem bisnis dan bukan sistem komputer. Artinya e-commerce harus merupakan solusi komprehensif dalam berbisnis, sehingga yang diurusi bukan sisi teknisnya semata tapi strategi, proses, organisasi dan manusianya:

2. Kemauan untuk terjun ke e-commerce

"1/bid.

${ }^{12}$ Redynal Saat. Op. Cit. 
harus didukung penuh oleh pimpinan tingkat atas. Bahasa lainnya, pimpinan atașlah penanggung jawab dan pemilik e-commerce ini.

3. Pembuatan proses bisnis harus terdefinisi secara eksak guna menghindari "pendewaan" teknologi dan komputer sebagai satu-satunya pembuat solusi.

4. Mengantisipasi kemungkinan munculnya konflik yang diakibatkan peralihan ke ecommerce. Konflik seperti ini sangat mungkin datang dari pihak ketiga yang merasa dirugikan dengan strategi baru ini.

5. Mengantisipasi kemungkinan gerakan anti perubahan (resistance to change) dari internal perusahaan.

6. Harus mempelajari demografi dan kebutuhan konsumen dalam rangka menyajikan pelayanan yang sebaikbaiknya kepada mereka; dan

7. Harus disiapkan tenaga-tenaga terampil bidang teknologi informasi yang mengerti e-commerce dengan segala persoalannya, termasuk Internet, Intranet, Web, Database, pengamanan sistem, dan masalahmasalah hukum yang terkait.

Di samping ketujuh langkah strategis di atas, untuk dapat mengoptimalisasikan transaksi e-commerce dalam meraup keuntungan, maka aspek hukum juga memegang peranan yang strategis sebagai jaminan bagi para pihak untuk mendapatkan perlindungan hukum apabila di kemudian hari ada sengketa (dispute).

Regulasi Hukum dalam Transaksi

\section{E-Commerce: Menuju Optimalisasi Pemanfaatan Teknologi}

Internet sudah merupakan bagian dari kehidupan yang menghubungkan setiap bagian dari kehidupan. Internet merupakan bagian dari mekanisme telekomunikasi yang bersifat global yang fungsinya menjadi jembatan bebas hambatan informasi. Perkembangan dunia maya tersebut ternyata membuat dan menciptakan berbagai kemudahan dalam hal menjalankan transaksi, dunia pendidikan, perdagangan, perbankan serta menciptakan jutaan kesempatan untuk menggali keuntungan ekonomis.

Peperangan antara Microsoft dengan departemen Antitrust, dimana perusahaan milik Bill Gates dianggap melanggar ketentuan tentang hukum antimonopoli, sehubungan dengan program terbaru Microsoft tahun 1998, dituduh dapat merugikan pihak lain karena program "browser" yang dapat digunakan untuk menjelajah dunia maya itu melekat di dalamnya. ${ }^{13}$

"Peperangan" ini tentunya tidak akan timbul apabila potensi ekonomis dari pengguna internet demikian besar serta penggunaannya yang akan menjadi bagian kehidupan moderen abad mendatang. Oleh sebab. itu internet tidak lagi dapat dipersonafikasikan sebagai sarana pornografi, yang merupakan pandangan yang sangat tendensius pada awal internet beredar. Jutaan dollar telah dihasilkan oleh mereka yang inovatif dalam memanfaatkan internet sebagai mesin uang, misalnya penemu Yahoo, yang mungkin awalnya hanya sebagai tempat para

\footnotetext{
${ }^{13}$ Indra Safitri. Hukum...Op.Cit.
} 
cyber, untuk mencari alamat atau informasi yang digunakan, namun "ide" ini membuat pemiliknya menjadi milyuner karena situs Yahoo merupakan situs yang paling banyak dikunjungi, sehingga menjadi tempat yang mahal untuk setiap pemasang iklan. ${ }^{14}$

Michael Chissik dan Alistair Kelman mengemukakan bahwa sekarang ini telah terjadi revolusi di dunia cyber khususnya ecommerce sebagaimana dikatakan:

"Everybody agrees that electronic commerce is going to revolutionize spending habits and change the way businesses conduct. The reasons are many and varied such as globalisation and the dismantling of trade barriers; the deployment of smart cards; the Internet; and the de facto emergence of English as the global language. ${ }^{15}$

Jaringan komputer global (internet) pada awalnya digunakan hanya untuk saling tukarmenukar informasi, fungsinya kemudian meningkat dari sekadar media komunikasi menjadi sarana untuk melakukan kegiatan komersial seperti informasi, penjualan dan pembelian produk. Keberadaannya menjadi sebuah intangible asset sebagaimana layaknya sebuah intellectual property. ${ }^{16}$

Perkembangan jasa internet menimbulkan dampak positif dan negatif. Dampak negatifnya adalah timbulnya apa yang disebut cybercrime (kejahatan cyber). Kejahatan cyber bukanlah kejahatan sederhana karena tidak menggunakan sarana konvensional, tetapi menggunakan komputer dan internet. Kejahatan cyber yang bisa terjadi antara lain penipuan cyber (cyber fraud), perusakan jaringan cyber (hacking); dan penyerangan melalui virus (virus attack) ${ }^{17}$

Di Indonesia dampak negatif ini tidak saja hanya sebatas diketahui, tetapi dalam praktik sudah banyak terjadi. Kasus tertangkapnya seorang WNI di Singapura dengan tuduhan ia telah melakukan kejahatan hacking yang melanggar cyberlaw di. Singapura. Pihak kepolisian Singapura menyatakan bahwa hacker Indonesia yang tertangkap akan dijerat dengan Undang-Undang Penyalahgunaan Komputer (Computer Misuse Act) yang dapat disebut juga sebagai Cyberlaw di Singapura. Hacker yang ditangkap tersebut adalah bocah berusia 15 tahun dari Malang dan datang ke Singapura pada 28 Mei 2000 dengan tujuan melakukan kunjungan biasa bersama keluarga. Setelah tertangkap, Senin (12 Juni 2000), sang hacker langsung dikenai tahanan negeri, alias tidak diperkenankan untuk keluar dari Singapura. Sebagai jaminan adalah dua orang warga negara Singapura teman sang hacker. Hacker tersebut melakukan tindakan hacking berkaitan dengan aktivitasnya di IRC (Internet Relay Chat),18 sangat representatif dikemukakan dan akan

${ }^{14}$ Ibid.

15Kompas. "Konflik Kepentingan di Dunia Cyber." http://www.kompas.com/kompas-cetak/0111/19/ NASIONAL/kOnf07.htm

${ }^{16} \mathrm{lbid}$.

${ }^{17}$ lbid.

${ }^{18}$ R.M. Roy Suryo. "Pentingnya Hukum di Jagat Maya internet." http://www.kontan-on/ine.com/04/43/ refleksi/ref2.htm 
sangat relevan dengan keinginan Indonesia untuk membentuk regulasi hukum di dunia cyberspace.

Aspek hukum yang berhubungan, dengan internet dan teknologinya disebut dengan cyberlaw, yaitu ketentuan hukum yang mengatur tentang mekanisme dan sistem yang dapat melindungi, menjaga dan memberikan keamanan kepada setiap pihak yang menggunakan internet sebagai sarana transaksi atau menyampaikan informasi yang tergolong dapat mempengaruhi dan mendorong pihak untuk ikut atau membeli informasi yang disampaikan tersebut. Sebagai sarana informasi yang skalanya global, pencurian, perusakan informasi adalah perbuatan yang tergolong pidana sehingga dapat ditukum dengan hukuman penjara. ${ }^{19}$

Beberapa hal yang perlu diatur dalam transaksi e-commerce, meliputi; pengaturan tentang cukai dan pajak dalam penggunaan aplikasi e-commerce; pengaturan yang berhubungan dengan pembayaran secara elektronik; Pengaturan tentang ketentuan hukum yang berhubungan dengan privacy dan keamanan dalam melakukan transaksi; kemampuan dan daya dukung yang dimiliki oleh jaringan infrastrukrur telokomunikasi dan standar teknis yang diterapkan di dalam perdagangan elektronik tersebut; dan pengaturan masalah yurisdiksi serta applicable law.
Hingga kini sudah ada beberapa negara yang mengatur tentang transaksi e-commerce. Negara-negara itu antara lain; Singapura telah memiliki The Electronic Act 1998 (undangundang tentang transaksi secara elektronik), serta Electronic Communication Privacy Act (ECPA). Di Amerika Serikat juga sudah ada Communication Assistance for Law Enforcement Act dan Telecommunication Service 96. Indonesia sendiri dalam regulasi hukum mengenai transaksi e-commerce masih baru sebatas perbincangan. Bahkan, rencana membuat regulasi hukum dalam transaksi e-commerce, telah menimbulkan tarik menarik dari dua kepentingan yang berbeda. ${ }^{20}$ Alhasil, regulasi hukum tersebut hingga kini hanya menjadi wacana. Kalau pun ada aturan yang sudah mengatur masalah transaksi e-commerce, itu pun sifatnya masih sangat parsial dan terialu kecil. Sebagai contoh; tentang perlunya data elektronik sebagai alat bukti. Hal ini sudah diatur dalam UU No. 15 Tahun 2002 tentang Tindak Pidana Pencucian Uang. ${ }^{21}$ Akan tetapi, pengaturan yang sedikit ini dirasa belum cukup untuk mengakomodasi permasalahan hukum yang muncul dalam transaksi e-commerce. Oleh karena itu, kebutuhan terhadap pengaturan secara komprehensif dan integral, serta memperhatikan pengaturan-pengaturan yang sudah ada adalah sesuatu yang tidak dapat ditolak lagi.

\section{${ }^{19}$ Indra Safitri. Op. Cit.}

20Perlunya cyberlaw di Indonesia muncul setelah adanya perdebatan antara dua lembaga akademis: Lembaga Kajian Hukum Teknologi (LKHT) FH UI dan Center of Cyber Law Studies (CCLS) Unpad. Kedua lembaga ini sama-sama tengah mengembangkan RUU cyberlaw.

21Pasal 44 huruf f UU No. 15 Tahun 2002 dinyatakan bahwa alat bukti lain berupa informasi yang diucapkan, dikirim, diterima atau disimpan secara elektronik dengan alat optik atau alat lain yang serupa dengan itu tetapi tidak terbatas pada electronic data interchange, surat elektronik, telegram, teleks atau faksimili. 
Bentuk Pengaturan yang tepat berupa undang-undang yang mengatur secara lengkap mengenai seluk beluk transaksi ecommerce. Pemilihan dalam bentuk undangundang semata-mata didasarkan pada pertimbangan bahwa undang-undang kedudukannya lebih kuat ketimbang peraturan di bawah undang-undang, seperti Peraturan Pemeritah dan Keputusan Presiden. Di lain pihak, dengan dibuat ke dalam bentuk undang-undang, maka partisipasi publik akan banyak terlibat dalam proses pembentukan undang-undang ini, terutama dari kalangan masyarakat cyber.

Namun demikian, apabila undangundang ini belum terbentuk bukanlah berarti masalah hukum yang timbul dari transaksi ecommerce tidak dapat diselesaikan. Ada dua pendekatan yang dapat dilakukan, yakni; Pertama, melalui pendekatan hukum konvensional (exsiting law). Caranya, ketika terjadi sengketa di antara kedua pihak, maka para pihak dapat mengajukan tuntutan ke pengadilan. Di sana nantinya hakim akan berupaya untuk melakukan penemuan hukum. Penemuan hukum ini dilakukan atas dasar hakim tidak boleh menolak perkara dengan alasan tidak ada hukumnya (ius curia novit). Akhirnya nanti hakim akan melakukan penafsiran hukum terhadap hukum konvensional dengan cara analogi hukum. Dari sinilah hukumnya dapat ditentukan.

Apabila sengketa itu terjadi dalam konteks lintas batas negara (bonderless world), maka sebelum ketentuan hukum suatu negara diberlakukan perlu diperhatikan dulu apsek choice of law dan choice of forum yang dipilih para pihak. Baru setelah diketemukan hukum mana yang diterapkan dan dalam yurisdiksi siap hukum itu diterapkan masalah sengketa para pihak akan dapat diselesaikan.

Kedua, dalam masalah pengakuan pembuktian terhadap data elektronik dapat disiasati dengan cara membuat aturan yang dibuat dan disepakati oleh para pihak secara bersama-sama. Model ini dikenal dengan istilah selfregulation. Model ini sudah diterapkan oleh uww.bca.com dalam salah satu klausul sistem pembayaran melalui internet banking milik BCA. Dalam klausulnya itu dikatakan bahwa para pihak bersepakat semua data elektronik yang ada dalam web www.bca.com dapat dijadikan alat pembuktian.

Implikasi yang diharapkan dari pengaturan supaya para pengguna jasa layanan internet yang selama ini merasa tidak aman, akan merasa terjamin dengan keberadaan pengaturan hukum mengenai transaksi e-commerce. Secara otomatis, ketika jaminan keamanan itu sudah ada dari segi yuridis para pengguna jasa layanan internet akan semakin meningkatkan pemanfaatan teknologi informasi ini. Menurut Lawrence, pengaturan hukum yang tepat dalam masalah ini adalah suatu sistem hukum yang dapat memveto suatu bentuk inovasi yang tidak disukai karena hanya akan merusak sistem. ${ }^{22}$ Artinya, hukum yang diformulasikan hendaknya mampu mengantisipasi segala bentuk pengrusakan terhadap sistem teknologi informasi.

Sebagai catatan penting lainnya, pengaturan transaksi e-commerce yang dimaksudkan bukan dioreintasikan kepada pengaturan masalah teknologinya, tetapi lebih dititik 
beratkan kepada pola hubungan antar pelaku dalam transaksi e-commerce. Hal ini penting, sebab apabila pengaturan transaksi e-commerce mendasarkan pada aspek teknologi, maka tak pelak lagi pengaturan hukum tersebut akan cepat ketinggalan atau lekas usang. Sudah dapat dipastikan bahwa dengan perkembangan teknologi informasi, terutama internet perubahan itu hampir dapat dipastikan bukan lagi dalam hitungan hari, tetapi hampir setiap detik.

\section{Simpulan}

Kehadiran teknologi informasi (internet) yang semula dimanfaatkan untuk kepentingan militer di AS dan pendidikan, kini telah berkembangan ke segala sektor kehidupan. Sektor perdagangan merupakan salah satu bagian yang tidak terlepas dari pemanfaatan teknologi informasi ini. Hal ini dibuktikan dengan kehadiran transaksi e-commerce. Dalam transaksi e-commerce ini banyak permasalahan hukum yang berkembang, sehingga pengaturan hukum yang jelas dan tegas terhadap masalah transaksi e-commerce sangat dibutuhkan sebagai jaminan perlindungan hukum bagi para pihak. Konkritisasi dari pengaturan ini hendaknya segera dibuat undang-undang yang mengatur masalah transaksi e-commerce.Harapan yang dikehendaki, dengan pengaturan hukum yang jelas dan tegas, maka pemanfaatan teknologi informasi akan semakin optimal, terutama untuk kebutuhan transaksi e-commerce. $\square$

\section{Daftar Pustaka}

"Bisnis Internet Suram." http://www. bwhostingforum.com/viewthread. php?tid=47.
Hardhini, Sheilla. "Penyelesaian Sengketa Business to Business dan Business to Consumer Electronic Commerce Melalui Litigasi dan Arbitrase di Indonesia." http://www.cyberlaw.lkht.org/ penelitian/penyelesaian sengeta b208b2c libigasi arbitasi shehtm

Kompas. "Konflik Kepentingan di Dunia Cyber." http://www.kompas.com/kompascetak/0111/19/NASIONALI konf07.htm

Saat, Redynal. "Electronic Commerce Peluang dan Kendala." http:/l www.cyberlaw.Ikht.org/arsip/ ecommerce peluang atau kendata redhtom

Safitri, Indra. "Commerce dalam Perspektif Hukum."

http:/l

business. fortunecity.com/buffett/ 842/art080399 ecommerce.htm

. "Hukum tentang Cyber dan Teknologi di Pasar Modal Indonesia." http:// business, fortunecity.com/buffett/ 842/art000011 hukumcyber.

Sitompul, Asri. 2001. Hukum Internet Pengenalan Mengenai Masalah Hukum di Cyberspace. Bandung: Citra Aditya Bakti.

Suherman, Ade Maman. 2002. Aspek Hukum dalam Ekonomi Global. Jakarta: Ghalia Indonesia.

Suryo, R.M. Roy. "Pentingnya Hukum di Jagat Maya Internet." http://www.kontanonline.com/04/43/refleksi/ref2.htm

Ridwan Khairandy. "Pembaharuan Hukum Kontrak sebagai Antisipasi Transaksi E-Commerce." Jurnal Hukum No. 16 Vol 8 Maret 2001.

Turban, Efraim, et.el. 2001. Electronic Commerce: Manajemen Perspective. New Jersey: Prentice-Hall Inc. 